\title{
Comparative Study of Chemotherapy and/or Immunotherapy of Established Experimental Brain Tumors
}

\author{
Yoshihisa KIDA and Humberto CRAviOTO* \\ Department of Neurosurgery, Kamo Hospital, Toyota, Aichi; \\ *Department of Pathology, New York University Medical Center, \\ New York, U.S.A.
}

\begin{abstract}
Intracerebral injection of $5 \times 10^{5}$ nitrosourea-induced glioma cells $\left(\mathrm{T}_{9}\right.$ tissue culture line) consistently produced brain tumors in syngenic Cesarean Derived Fisher rats. The tumors were $1 \mathrm{~mm}$ in diameter within 7 days and caused death within 23 days (mean results). The effects of therapy with ACNU and/or Corynebacterium parvum (C. parvum) were evaluated. C. parvum alone was apparently ineffective. ACNU (10 mg $/ \mathrm{kg}$ body weight) given on days 7 and 14 prolonged the mean survival time to 33.4 days. Combined treatment with ACNU and intradermal immunization with $\mathrm{T}_{9}$ cells and $C$. parvum on days 7 and 14 , or on days 0 and 7 , prolonged the mean survival time to 35.3 and 39.6 days, respectively. Eleven rats that survived following this treatment showed specific immunity against $T_{9}$ cells, as demonstrated by subsequent challenge with $T_{9}$ cells. The Winn's test procedure showed that spleen lymphocytes from immune rats were effective against $T_{9}$ cells. The results suggest that immunochemotherapy may be an effective treatment for rats with established brain tumors.
\end{abstract}

Key words: brain neoplasms, chemotherapy, immunotherapy, Corynebacterium parvum

\section{Introduction}

Despite recent achievements in operative methods, radiation therapy, and chemotherapy, either alone or combined, results of treatment of human malignant brain tumors are still poor. ${ }^{34,35)}$ The use of anticancer nitrosourea compounds, BCNU, CCNU, Me-CCNU, PCNU, chlorozotocin, and streptozotocin in the treatment of brain tumors has been only moderately effective. ${ }^{34-37)}$ This is also true for ACNU, a water-soluble nitrosourea compound ${ }^{3)}$ that is similarly effective in the treatment of both experimental ${ }^{1724}$ and human malignant brain tumors. ${ }^{29,30)}$ Other means of treating induced brain tumors, such as immunologic modalities, have also shown only minor and inconsistent success. ${ }^{25,26,42)} \mathrm{A}$ combination of chemotherapy and immunotherapy may be synergistic, since chemotherapy may retard tumor growth and thus allow more time for im- munologic mechanisms to destroy tumor tissue. This approach has been tried clinically, ${ }^{2,22,31,41)}$ with conflicting results. Further experimentation with both treatment modalities is therefore necessary.

A formalin-killed suspension of Corynebacterium parvum (C. parvum) was used because it appears to be a nonspecific immunostimulant ${ }^{12,37)}$ as well as a specific immunomodulator ${ }^{19,32,33)}$ and has also been shown to be somewhat effective in the treatment of experimental non-neural tumors. ${ }^{12,39)}$ In our experiments, we sought to determine the effects on neurogenic tumor growth of treatment with $C$. parvum alone, $\mathrm{ACNU}$ alone, $\mathrm{ACNU}$ plus $C$. parvum, tumor immunization alone, and ACNU plus tumor immunization. We also studied the immunologic competence of rats whose mean survival, following combined modality treatment (chemoimmunotherapy), was more than twice as long as that of controls. 


\section{Materials and Methods}

\section{Tumor cell line}

Cell line $T_{9}$ was obtained in culture form, through the courtesy of Dr. R. Denlinger. This line originated from a young male inbred Cesarean Derived Fisher (CDF) rat injected weekly, for 36 weeks, with $5 \mathrm{mg} / \mathrm{kg}$ body weight of methylnitrosourea (MNU). ${ }^{5}$ The brain tumor from which the $T_{9}$ cell line was derived was histologically designated as astrocytoma, grade III. We have previously reported the in vitro sensitivity to ACNU of this tumor cell line. ${ }^{20)}$ We used another rat glioma cell line, EB679, to investigate specificity of immunity. This line was originally a cerebral glioma induced with ethylnitrosourea transplacentally by Dr. W. Wechssler of West Germany. A clone (RG-2) of this cultured rat glioma (in vitro passage 5) was kindly given to us by Dr. D. Bigner of Duke University in North Carolina.

\section{Animals}

CDF inbred male rats were purchased from Charles River Co. and were used throughout these experiments. Their mean weight was approximately $150 \mathrm{~g}$.

\section{Development of brain tumor model}

Adult male rats were anesthetized with inhalation of ether and intraperitoneal injection of ketamine and placed in a small-animal stereotaxic head holder. The scalp was incised and the skull drilled with a dental drill $1 \mathrm{~mm}$ anterior to the bregma and $2 \mathrm{~mm}$ to the right of the mid-sagittal line. A $20 \mu$ l tumor cell suspension containing $5 \times 10^{5} \mathrm{~T}_{9}$ cells was injected intracerebrally (IC) through this opening, via a $27 \mathrm{G}$ Hamilton microsyringe, to a depth of $5 \mathrm{~mm}$ (coincident with the right caudate nucleus). The skull was then sealed with bone wax and the scalp was sutured. The rats were observed daily for their general condition and development of neurological signs. When they became preterminal, they were sacrificed. The brains were removed and fixed in $10 \%$ formaldehyde, cut into 1-2 mm coronal slices, and embedded in paraffin. Sections were stained with hematoxylin-eosin.

\section{Treatment of the brain tumor model}

ACNU: $25 \mathrm{mg}$ of ACNU in powder form was dissolved in $5 \mathrm{ml}$ of Dulbecco's phosphate buffer saline and injected into the animals intravenously (IV).

C. parvum: A formalin-killed suspension of $C$. parvum supplied at a concentration of $7 \mathrm{mg}$ dry weight bacteria $/ \mathrm{ml}$ was administered intraperitoneal-
Table 1 Therapeutic regimens used in experimental brain tumors in rats

$\begin{array}{cl}\text { Group } & \text { Treatment regimens } \\ 1 & \text { Control (no treatment) } \\ 2 & \text { C. parvum ID on days } 7 \text { and } 14 \\ 3 & \text { C. parvum IP on days } 7 \text { and } 14 \\ 4 & \text { T }_{9} 10^{6}+C \text {. parvum ID on days } 0 \text { and } 7 \\ 5 & \text { T }_{9} 10^{6}+C \text {. parvum ID on days } 7 \text { and } 14 \\ 6 & \text { ACNU alone IV on days } 7 \text { and } 14 \\ 7 & \text { ACNU IV on days } 7 \text { and } 14+ \\ 8 & \text { C. parvum IP on days } 8 \text { and } 15 \\ 9 & \text { ACNU IV on days } 7 \text { and } 14+ \\ 9 & \text { AC. parvum IV on days } 8 \text { and } 15 \\ & \left(T_{9} 10^{6}+C \text {. parvum) ID on days } 8 \text { and } 15\right. \\ 10 & \text { ACNU IV on days } 7 \text { and } 14+ \\ & \left(\text { T } 10^{6}+C \text {. parvum) ID on days } 0 \text { and } 7\right.\end{array}$

C. parvum: Corynebacterium parvum, ID: intradermal administration, IP: intraperitoneal administration, IV: intravenous administration.

ly (IP), intradermally (ID), or IV.

Ten different methods of treatment were employed in our experiment, as shown in Table 1. C. parvum was administrated as $2 \times 10^{8}$ formalin-killed bacterial particles $(0.14 \mathrm{mg})$ in each injection at days 7 and 14 . ACNU was injected at $10 \mathrm{mg} / \mathrm{kg}$ body weight at days 7 and 14. C. parvum, either alone or mixed with $\mathrm{T}_{9}$ tumor cells, was used for active immunization. When C. parvum was combined with ACNU, it was injected at days 8 and 15 . In groups 4 and 10 , this tumor immunization was given at days 0 and 7 . Previous experiments ${ }^{19}$ have shown that after ID immunization with $2 \times 10^{8} \mathrm{C}$. parvum mixed with $1 \times 10^{6} \mathrm{~T}_{9}$ cells, the ID tumor challenges are rejected, whereas IC challenges are not fully suppressed.

\section{Evaluation of the immunological status}

Rechallenge with $\mathbf{T}_{9}$ cells: Rats that survived for more than 50 days were considered long survivors. They were challenged ID with $5 \times 10^{5} \mathrm{~T}_{9}$ cells, and then with $10^{6}$ cells ID if the first challenge was rejected. Subsequently, the rats were challenged with $10^{6} \mathrm{~T}$, cells IC in the left frontal lobe.

Challenge with EB679 cells: Some of the long survivors were injected ID with $5 \times 10^{5}$ EB679 gliosarcoma cells to study the specificity of the immunity. These ID tumors were measured with calipers weekly and compared with those of the controls.

Winn's assay: After ID and IC challenges, as described above, the rats were sacrificed and their spleens were used for Winn's test. ${ }^{38)}$ Briefly, the Winn's test was performed as follows. Spleen cells 
were harvested aseptically from treated and from normal, untreated rats. Mixtures of spleen cells as a ratio of $25: 1\left(7.5 \times 10^{6}\right.$ spleen cells mixed with $3 \times 10^{5}$ $T_{9}$ cells) were injected ID into the backs of six normal rats. Tumor growth was measured weekly for up to 28 days after injection.

\section{Statistical analysis}

The data obtained in our experiments were studied with the combined Student's T test for comparison of tumor size and survival time.

\section{Results}

\section{Effects of treatment}

Injection of $5 \times 10^{5} \mathrm{~T}_{9}$ cells consistently produced tumors in syngenic CDF rats. All IC injected rats had established tumors, $1 \mathrm{~mm}$ in diameter, within 7 days (Fig. 1), and all died from the tumor (within an

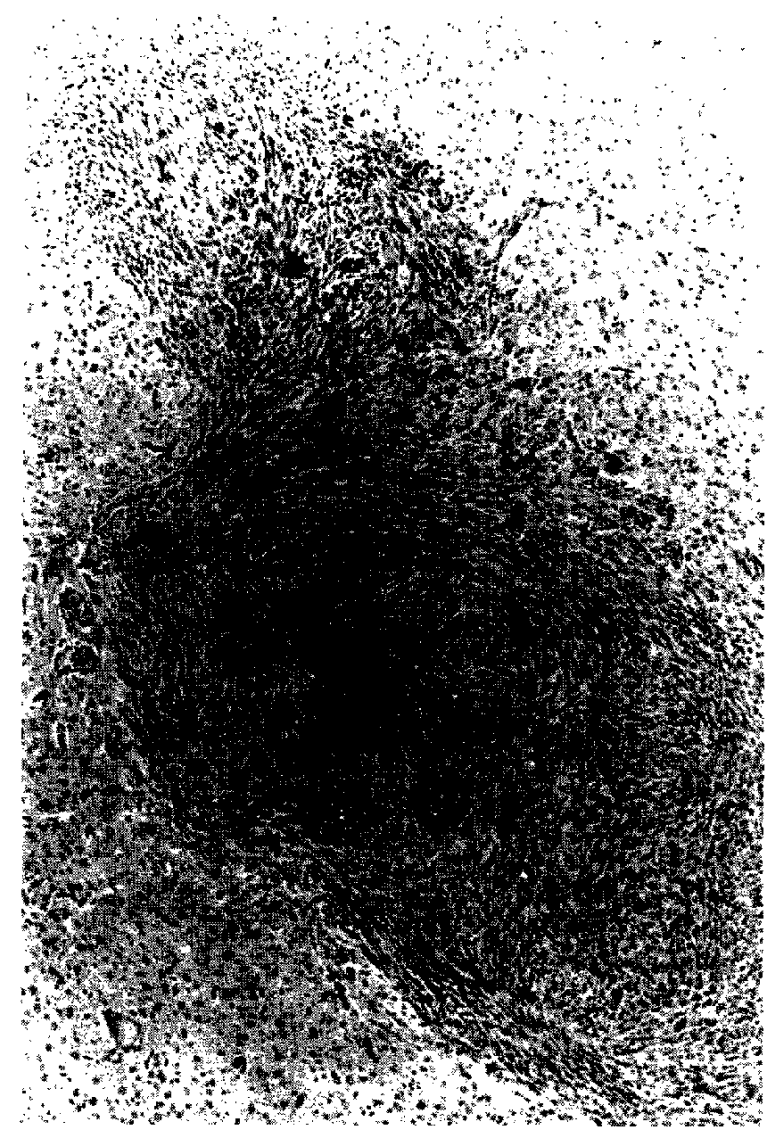

Fig. 1 Intracerebral tumor of control rat on 7 th day after inoculation. The tumor is $1 \mathrm{~mm}$ in diameter. No necrotic foci or significant lymphocytic infiltration are evident. HE stain, $\times 40$.
Table 2 Results of treatment of established $\mathrm{T}_{9}$ brain tumor with ACNU and/or C. parvum

\begin{tabular}{|c|c|c|c|c|}
\hline Group & $\begin{array}{l}\text { Total } \\
\text { No. }\end{array}$ & $\begin{array}{l}\text { Mean } \\
\text { survival } \\
\text { (days) }\end{array}$ & $\begin{array}{c}\text { Increased } \\
\text { lifespan } \\
(\%)\end{array}$ & $\begin{array}{c}\text { Long } \\
\text { survivors } \\
\text { (>50 days) }\end{array}$ \\
\hline 1 & 14 & $23.0 \perp 1.5 \mathrm{SE}$ & - & 0 \\
\hline 2 & 8 & $21.6 \perp 0.7$ & -6.1 & 0 \\
\hline 3 & 6 & $18.3 \pm 0.2$ & -20.0 & 0 \\
\hline 4 & 8 & $25.0 \pm 2.4$ & 8.7 & 0 \\
\hline 5 & 8 & $23.1 \pm 1.2$ & 0.4 & 0 \\
\hline 6 & 8 & $\begin{array}{l}33.4 \pm 3.2 \\
(\mathrm{p}<0.001)^{*}\end{array}$ & 45.2 & $1(12.5 \%)$ \\
\hline 7 & 8 & $\begin{array}{l}31.4+2.1 \\
(\mathrm{p}<0.005)^{*}\end{array}$ & 36.5 & 0 \\
\hline 8 & 8 & $28.3 \pm 4.8$ & 23.0 & $1(12.5 \%)$ \\
\hline 9 & 14 & $\begin{array}{l}35.3 \pm 2.3 \\
(\mathrm{p}<0.001)^{*}\end{array}$ & 53.5 & $3(21.4 \%)$ \\
\hline 10 & 15 & $\begin{array}{l}39.6+2.9 \\
(\mathrm{p}<0.001)^{*} \\
(\mathrm{p}<0.05)^{* *}\end{array}$ & 71.7 & $6(40.0 \%)$ \\
\hline
\end{tabular}

Statistically significants when compared with ${ }^{*}$ controls, and with ${ }^{* *} \mathrm{ACNU}$ alone.

average of 23 days). The results of the various treatments are shown in Table 2. When the rats were treated with IP or ID injections of $0.14 \mathrm{mg}$ of C. parvum alone at days 7 and 14, the survival time of treated rats was not prolonged. IP injection of $C$. parvum actually decreased the survival time of treated rats, compared with that of controls. When rats were immunized with injections of $10^{6}$ live $T_{9}$ cells mixed with $0.14 \mathrm{mg}$ of $C$. parvum at days 0 and 7 or days 7 and 14, the survival time was not significantly prolonged (mean survival: 25.0 and 23.1 days, respectively).

ACNU ( $10 \mathrm{mg} / \mathrm{kg}$ body weight) given on days 7 and 14 significantly prolonged the mean survival time to 33.4 days (range, 22 to 43 days); one rat survived more than 50 days. Combination treatment with ACNU and IP or IV C. parvum also extended the survival time, but by no more than treatment with ACNU alone. ACNU plus tumor immunization at days 8 and 15 lengthened survival time more than did ACNU alone, but the difference was not significant. However, when tumor immunization was started at day 0 and followed by ACNU administration, the effects were more obvious and significant; the mean survival time increased to 39.6 days, and all such treated rats survived more than 30 days. Six of 15 rats treated in this manner survived more than 50 days.

\section{Immunologic status of long survivors}

Eleven rats survived more than 50 days. This 
Table 3 Immunologic status of "long survivors"

\begin{tabular}{|c|c|c|c|c|c|c|c|}
\hline & Rat No. 1 & No. 2 & No. 3 & No. 4 & No. 5 & No. 6 & Nos. 7-11 \\
\hline Treatment & $\begin{array}{l}\text { ACNU } \\
\text { alone }\end{array}$ & $\begin{array}{c}\mathrm{ACNU}+ \\
\left(\mathrm{T}_{9}+C \cdot p .\right) \\
\mathrm{ID}(8 \& 15 \mathrm{~d})\end{array}$ & $\begin{array}{c}\mathrm{ACNU}+ \\
\left(\mathrm{T}_{9}+C \cdot p .\right) \\
\mathrm{ID}(8 \& 15 \mathrm{~d})\end{array}$ & $\begin{array}{c}\mathrm{ACNU}+ \\
\left(\mathrm{T}_{9}+C . p .\right) \\
\mathrm{ID}(8 \& 15 \mathrm{~d})\end{array}$ & $\begin{array}{c}\text { ACNU+ } \\
\text { C.p. IV } \\
(8 \& 15 \mathrm{~d})\end{array}$ & $\begin{array}{c}\text { ACNU+ } \\
\left(\mathrm{T}_{9}+C \cdot p .\right) \\
\mathrm{ID}(0 \& 7 \mathrm{~d})\end{array}$ & $\begin{array}{c}\text { ACNU+ } \\
\left(\mathrm{T}_{9}+C \cdot p .\right) \\
\text { ID }(0 \& 7 \mathrm{~d})\end{array}$ \\
\hline $\begin{array}{l}\text { Rechallenge with } \\
\qquad 10^{6} \mathrm{~T}_{9} \text { ID }\end{array}$ & rejection & $\approx$ control & $\approx$ control & rejection & rejection & rejection & rejection* \\
\hline $\begin{array}{l}\text { Rechallenge with } \\
10^{6} \mathrm{~T}_{9} \text { IC }\end{array}$ & - & - & - & - & rejection & rejection & - \\
\hline $\begin{array}{l}\text { Challenge with } \\
5 \times 10^{5} \text { EB679 ID }\end{array}$ & $\approx$ control & - & - & - & $\approx$ control & - & 一 \\
\hline Winn's test & negative & - & - & - & positive** & positive** & - \\
\hline Brain histology & no tumor & no tumor & $\begin{array}{l}\text { large IC } \\
\text { tumor }\end{array}$ & no tumor & no tumor & no tumor & no tumor \\
\hline
\end{tabular}

${ }^{*}$ See Table 4, **see Fig. $2 . \quad$ IC: intracerebral.

represents $13.3 \%$ of all treated rats and $20.8 \%$ of rats treated with either ACNU alone or ACNU combined with $C$. parvum. None of the rats treated without ACNU survived more than 50 days. A summary of the immunologic status of the long survivors is shown in Table 3.

Rechallenge with $\mathbf{T}_{9}$ cells: ID tumor challenge with $10^{6} \mathrm{~T}_{9}$ cells (injected on day 50 ) was rejected by nine of 11 long-surviving rats (Table 3). Subsequent IC challenge of $10^{6} \mathrm{~T}_{9}$ cells to two rats who rejected the ID challenge was also rejected. Comparison of ID tumor growth in the five long survivors with that in normal rats is shown in Table 4; there were marked differences in tumor "take" (tumorigenesis) and size.

Challenge with EB679 cells: ID injection of $5 \times 10^{5}$ EB679 gliosarcoma cells in two of the long survivors induced tumors in both rats as in controls (Table 3).

Winn's assay: Winn's assay was performed in three long survivors. When tested, two rats had an ID EB679 tumor and the other one was totally free of the tumor (Table 3). Although one of them showed no significant effects, the other two demonstrated

Table 4 Results of ID challenges in "long survivors" (Nos. 7-11) with $T_{9}$ tumor cells

\begin{tabular}{ccccc}
\hline & \multicolumn{4}{c}{ Tumor "take" and size (mean, mm) } \\
\cline { 2 - 5 } & 1 week & 2 weeks & 3 weeks & 4 weeks \\
\hline Long survivors & 2.0 & $2.3^{*}$ & $3.0^{*}$ & $3.6^{*}$ \\
$(\mathrm{n}=5)$ & $(3 / 5)$ & $(2 / 5)$ & $(1 / 5)$ & $(1 / 5)$ \\
Control & 2.0 & 9.8 & 14.3 & 29.6 \\
$(\mathrm{n}=3)$ & $(3 / 3)$ & $(3 / 3)$ & $(3 / 3)$ & $(3 / 3)$ \\
\hline
\end{tabular}

*Statistically significant $(\mathrm{p}<0.05)$. $n$ : number of rats. a remarkable suppression of tumor growth when compared with controls, as shown in Fig. 2.

Pathology of the brain: With one exception, autopsies revealed no tumor growth in the brains of any of the long survivors. The brain injection sites were filled with fibrous tissue or cystic lesions surrounded by lymphocytic infiltration.

\section{Discussion}

The tumor we used was originally induced with MNU and has been perpetuated as $T_{9}$ or $9 \mathrm{~L}$ gliosarcoma by serial subcultures and animal passages." Other investigators ${ }^{4,10,21)}$ have also used the $\mathbf{T}_{9}$ brain tumor model to determine the efficacy of various therapeutic regimens. Levin et al. ${ }^{21)}$ compared the therapeutic effects of seven nitrosourea compounds in this model, and observed an increase in survival time with PCNU treatment followed by $\mathrm{BCNU}$, CCNU, and Me-CCNU administration. Barker et $a l .{ }^{4}$ showed that a dose of $\mathrm{BCNU}$, at approximately $40 \%$ of the $10 \%$ lethal dose, increased the lifespan of $38 \%$ of the animals when given 9 and 16 days after tumor inoculation. In our investigation with induced $\mathrm{T}_{9}$ brain tumors, weekly injection of $10 \mathrm{mg} / \mathrm{kg}$ of $\mathrm{ACNU}$ increased the mean survival time by $45.2 \%$. Of interest is that ACNU treatment, either alone or combined with other treatment modalities, "cured" $20.8 \%$ of rats with brain tumors. These results corroborate those of our in vitro studies of $T_{9}$ cell sensitivity to ACNU. ${ }^{20)}$

It has been reported ${ }^{6,12,27,33)}$ that both specific and nonspecific immune mechanisms are involved in the antitumor action of C. parvum. However, in several published studies, the systemic injection of $C$. parvum disturbed normal immune reactions ${ }^{6)}$ and facilitated tumor growth, depressed in vitro 

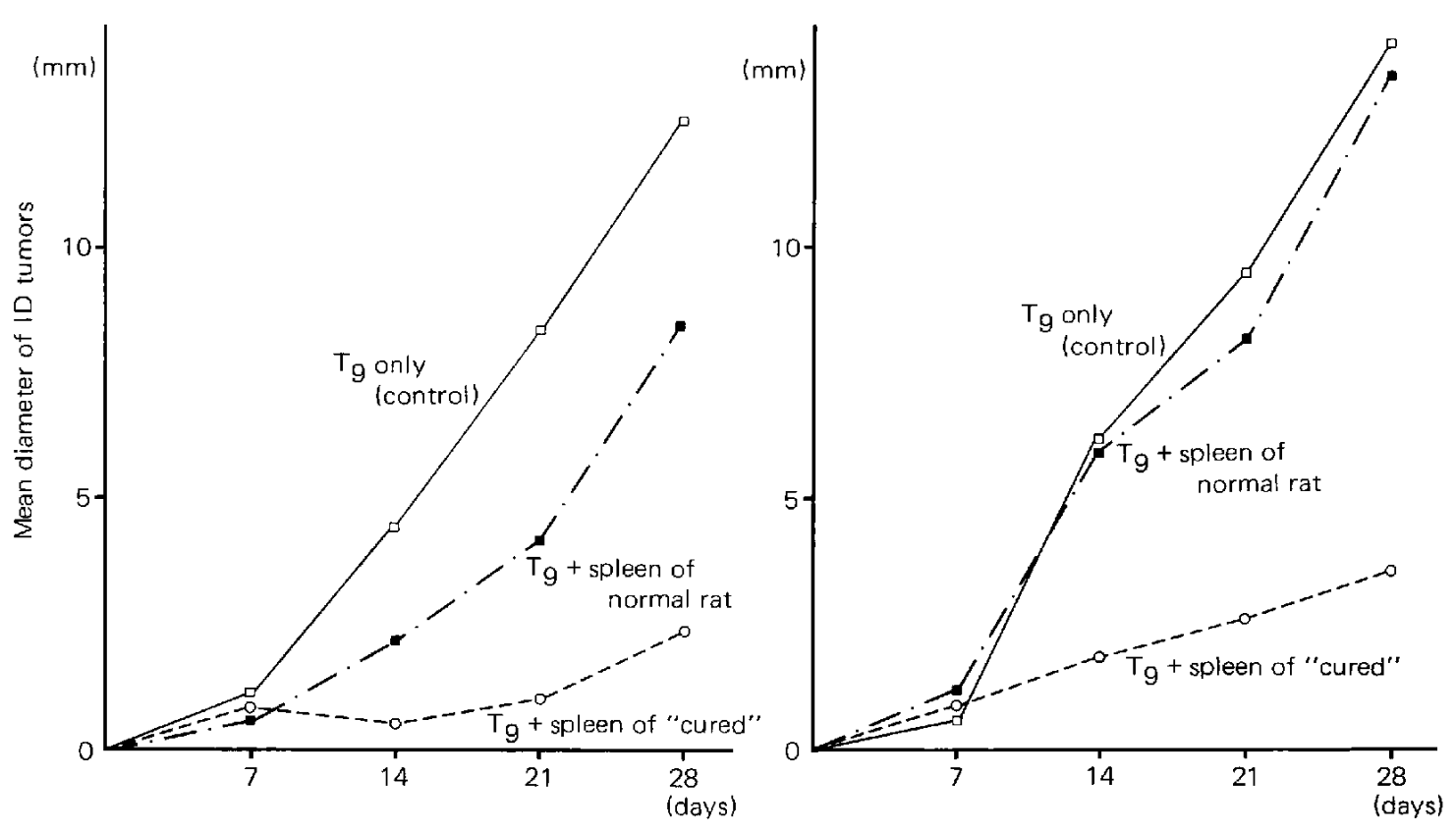

Fig. 2 Winn's test with spleen cells from two "long survivors," No. 5 rat (left) and No. 6 rat $(r i g h t)$. $\bigcirc--O$ : injected ID with a mixture of $3 \times 10^{5} \mathrm{~T}_{9}$ tumor cells and $7.5 \times 10^{6}$ spleen cells of long survivors ( $1: 25$ ratio), $\square$ : injected ID with a mixture of $3 \times 10^{5} \mathrm{~T}_{9}$ tumor cells and $7.5 \times 10^{6}$ normal spleen cells, $\square-\square$ : injected with $3 \times 10^{5} \mathrm{~T}_{9}$ tumor cells only (control). Each mark represents the average tumor size in six rats.

cell-mediated cytotoxicity, ${ }^{16,23)}$ and increased the myelotoxicity of concomitant chemotherapy. ${ }^{13,14)}$ Moreover, only a small amount of $C$. parvum is distributed to the central nervous system after IV injection $^{11,28)}$ and it may raise the intracranial pressure. ${ }^{31)}$ Therefore, it appears inappropriate or premature to use $C$. parvum systemically for the treatment of brain tumors. In our experiments, IV and IP injections of C. parvum alone could not suppress brain tumor growth, and actually shortened the lifespan of rats with brain tumors. When ACNU was combined with systemic administration of $C$. par$v u m$, the antitumor effects of ACNU apparently decreased and its myelotoxicity may have been enhanced. On the other hand, some investigators have reported that $C$. parvum, injected as a form of admixture with tumor cells, consistently suppressed tumor growth and induced systemic tumor immunity, especially in highly immunogenic tumors ${ }^{6,19,237}$ and sometimes even in poorly immunogenic tumors. ${ }^{\text {p) }}$ These findings applied to the $T_{9}$ brain tumor model. In fact, immunization with $C$. parvum mixed with $T_{9}$ tumor cells suppressed subsequent ID and IC tumor challenges and induced specific antitumor immunity, which was partially effective in brain tumors ${ }^{19}$ and readily transferable to normal rats. ${ }^{32)}$
In studies of extracranial tumor systems, the effects of chemotherapy have been increased by preimmunization or adoptive immune transfer with antibody or cytotoxic cells. However, in the treatment of established brain tumors this is not the case. In the chemoimmunotherapy of extracranial tumors, possible roles for chemotherapeutic drugs are: (1) reduction of tumor cells to the extent that the immune system can eliminate them, ${ }^{8)}$ (2) retardation of tumor growth until effective tumor immunity can be developed by the host, ${ }^{8}$ (3) modification of tumor cells to increase their susceptibility to immune mechanisms, ${ }^{7}$ (4) alteration of tumor cells to increase tumor immunity, ${ }^{15)}$ and (5) removal of suppressor $\mathrm{T}$ cells or suppressor macrophages that may inhibit the host's antitumor immunity. ${ }^{18)}$

Immunochemotherapeutic trials have been conducted with experimental brain tumors. Albright et $a l .{ }^{\text {1) }}$ reported the results of chemoimmunotherapy with CCNU and mitomycin-treated glioma cells and/or BCG that was started 3 or 4 days after tumor inoculation. Compared with $\mathrm{CCNU}$ administration alone, the combination treatment did not increase the survival time of animals with the brain tumors. In our experiments, immunization with live tumor cells mixed with $C$. parvum apparently enhanced the 
chemotherapeutic effect of $\mathrm{ACNU}$, though the combined effects were not great enough to eradicate the brain tumors completely. However, when the active immunization was applied earlier, the results appeared to be better.

The specific antitumor immunity demonstrated by long survivors is notable. Long survivors rejected or retarded IC inoculated tumor cells as well as subsequent IC and ID $T_{9}$ cell challenges. Therefore, it is conceivable that antitumor immunity was developed during treatment and contributed to the "cure" of brain tumors. More importantly, the induction of specific immunity might be indispensable for a complete "cure" following chemotherapy. It has been reported that following inoculation of brain tumors in mice, a specific killer $\mathrm{T}$ cell is generated in their spleens, and that spleen $T$ cells from these mice are cytotoxic to the inoculated tumor cells, ${ }^{40)}$ The Winn's test we performed tends to confirm this work. Whether or not humoral immunity was also involved in the eradication of brain tumors is still unclear. In our next study, we will attempt to identify a humoral tumor antibody in the serum of long survivors.

\section{Acknowledgment}

We are grateful to Drs. Gerald M. Hochwald and Jeannette G. Thorbecke for their advice and criticism of our manuscript.

\section{References}

1) Albright L, Madigan JC, Gaston MR, Hochens DP: Therapy in an intracerebral murine glioma model using bacillus calmetteguerin, neuroaminidase-treated tumor cells and 1-(2-chloroethyl)-3-cyclohexyl-1nitrosourea. Cancer Res 35:658-665, 1975

2) Apuzzo MLJ, Mitchell MS: Immunological aspects of intrinsic glial tumors. $J$ Neurosurg 55: 1-18, 1981

3) Arakawa M, Shimizu F, Okada N: Effect of 1-(4amino-2-methyl-pyrimidin-5yl) methyl-3-(2-chloroethyl)-3-nitrosourea hydrochloride on leukemia $\mathbf{L}$ 1210. Gan 65: 191, 1974

4) Barker $M$, Hoshino $T$, Gurcay $O$, Wilson $C B$, Nielsen RD, Eliason RD: Development of an animal brain tumor model and its response to therapy with 1,3-bis (2-chloroethyl)-1-nitrosourea. Cancer Res 33: 976-986, 1973

5) Benda P, Someda K, Messer J, Sweet WH: Morphological and immunochemical studies of rat glial tumors and clonal strains propagated in culture. $J$ Neurosurg 34: 310-323, 1971

6) Bomford R: Active specific immunotherapy of mouse methylcholanthrene induced tumours with Corynebacterium parvum and irradiated tumour cells. $\mathrm{Br} J$ Cancer 32: 551-557, 1975
7) Borsos T, Rapp $\mathrm{HJ}$ : Antigenic relationship between mycobacterium bovis and $\mathrm{BCG}$ in guinea pig hepatomas. I Natl Cancer Inst 51: 1985-1986, 1973

8) Chassoux DM, Gotch FM, MacLennan ICM: Analysis of synergy between cyclophosphamide therapy and immunity against a mouse tumor. $\mathrm{Br} J$ Cancer 38: 211-218, 1978

9) Cravioto HM, DeBernardo E, Hochwald GM, Thorbecke TJ: Immunity to transplantable nitrosourea-induced neurogenic tumors. I. Potentiation of tumor immunity with Corynebacterium parvum. $J$ Neuropathol Exp Neurol 40: 526-536, 1981

10) Denlinger RH, Axler DA, Koestner A, Liss L: Tumor-specific transplantable immunity to intracerebral challenge with cells from a methylnitrosourea-induced brain tumor. J Med 6: 249-259, 1975

11) Dimitrov NV, Denny TN, Weisman MF, Cameron DG: Effect of adriamycin and Corynebacterium parvum in tumor-bearing mice: Modulation of response to sheep red blood cells. I Nall Cancer Inst 63: 423426,1979

12) Fisher B, Wolmark N, Saffer E, Fisher ER: Inhibitory effect of prolonged Corynebacterium parvum and cyclophosphamide administration on the growth of established tumors. Cancer 35: 134-143, 1975

13) Foster RS: Altered toxicity of 5-fluorouracil following treatment with Corynebacterium parvum. Cancer Res 38: 850-858, 1978

14) Foster RS: Effect of Corynebacterium parvum on the proliferation rate of granulocyte-macrophage progenitor cells and the toxicity of chemotherapy. Cancer Res 38: 2666-2672, 1978

15) Fuji H, Mihich E, Pressman D: Differential tumor immunogenicity of L1210 and its sublines. I. Effect of an increased antigen density on tumor cell surfaces on primary B cell responses in vitro. J Immunol 119: 983-986, 1977

16) Gill PG, Waller CA, MacLennan ICM, Morris PJ: Effect of intravenous Corynebacterium parvum on peripheral-blood effector cells of cancer patients. $\mathrm{Br} \mathrm{J}$ Cancer 41: 782-789, 1980

17) Hasegawa $H$, Hayakawa $T$, Hori $M$, Nakagawa $H$, Mogami H, Nakata Y: Chemotherapy of experimental glioma with nitrosourea. Comparison of water soluble ACNU and lipid soluble MeCCNU. No To Shinkei 29: 891-898, 1977 (in Japanese)

18) Hengst JCD, Mokyr MB, Dray S: Cooperation between cyclophosphamide tumoricidal activity and host antitumor immunity in the cure of mice bearing large MOPC-315 tumors. Cancer Res 41: 2163-2167, 1981

19) Kida Y, Cravioto $H$, Hochwald GM, Hochgeschwender U, Ransohoff J: Immunity to transplantable nitrosourea-induced neurogenic tumors. II. Immunoprophylaxis of tumors of the brain. $J$ Neuropathol Exp Neurol 42: 122-135, 1983

20) Kida Y, Cravioto H, Hochwald GM, Ransohoff J: In vitro sensitivity of nitrosourea-induced neurogenic tumors to ACNU. Anticancer Research 2: 79-88, 
1982

21) Levin VA, Kabra P: Effectiveness of the nitrosourea as a function of their lipid solubility in the chemotherapy of experimental rat brain tumors. Cancer Chemother Rep 58: 782-792, 1974

22) Miki Y, Sano K, Takakura K, Mizutani H: Adjuvant immunotherapy with BCG for malignant brain tumors. Neurol Med Chir (Tokyo) 16 [Part 11]: 357364, 1976 (in Japanese)

23) Murahata RI, Zighelboim J: Inhibition of cellmediated cytotoxicity to tumor alloantigens by systemic administration of Corynebacterium parvum. Cancer Immunology and Immunotherapy 6: 101-106, 1979

24) Nakagawa $H$, Hori $M$, Hasegawa $H$, Mogami $H$, Hayakawa T, Nakata $Y$ : The anti-tumor effect of ACNU and $\mathrm{X}$-irradiation on mouse glioma. No To Shinkei 31: 927-936, 1979 (in Japanese)

25) Neuwelt EA, Clark K, Kirkpatrick JB, Toben H: Clinical studies of intrathecal autologous lymphocyte infusions in patients with malignant gliomas: A toxicity study. Ann Neurol 4: 307-312, 1978

26) Ommaya AK: Immunotherapy of gliomas. $A d v$ Neurol 15: 337-359, 1976

27) Pimm MV, Baldwin RW: C. parvum immunotherapy of transplanted rat tumors. Int $J$ Cancer 29: 923-932, 1977

28) Sadler TE, Cramp WA, Castro JE: Distribution of ${ }^{3}$ H-thymidine-labeled C. parvum in mice. Dev Biol Stand 38: 137-141, 1978

29) Saito T: Continuation of phase II study of 1-(4amino-2-methyl-pyrimidine-5yl) methyl-3-(2-chloroethyl)-3-nitrosourea hydrochloride (ACNU), in Carter SK, Sakurai Y (eds): Recent Results in Cancer Research. Berlin, Springer, 1980, pp 91-109

30) Saito Y, Nakaya Y, Muraoka K, Fujiwara T: Chemotherapy of brain tumors with nitrosourea derivative (ACNU). Gan To Kagakuryoho 4: 779794, 1978 (in Japanese)

31) Selker PG, Walmark N, Fisher B, Moore P: Preliminary observations on the use of Corynebacterium parvum in patients with primary intracranial tumors. Effect on intracranial pressure. $J$ Sturg Oncol 10: 299-303, 1978

32) Shibuya N, Hochgeschwender U, Kida Y, Hochwald GM, Thorbeche GJ, Cravioto $\mathrm{H}$ : Immunity to transplantable nitrosourea-induced neurogenic tumors. III. Systemic adoptive transfer of immunity. $J$ Neuropathol Exp Neurol 43: 426-438, 1984

33) Tuttle RL, North RJ: Mechanisms of antitumor action of Corynebacterium parvum: The generation of cell-mediated tumor specific immunity. J Reticuloendothet Soc 20: 197-208, 1976

34) Walker MD, Alexander E, Hunt WE, MacCarty CS, Mahaley MS, Mealey J, Norrell HA, Owens G, Ransohoff J, Wilson CB, Gehan EA, Strike TA: Evaluation of BCNU and/or radiotherapy in the treatment of anaplastic gliomas. A cooperative clinical trial. J Neurosurg 49: 333-343, 1978

35) Walker MD, Gehan EA: Clinical studies in malignant gliomas and their treatment with nitrosoureas. Cancer Treat Rep 60: 713-716, 1976

36) Wasserman TH, Slavik M, Carter SK: Clinical comparison of nitrosoureas. Cancer 36: 1258-1268, 1975

37) Weir B, Band P, Urtasun B: Radiotherapy and CCNU in the treatment of high grade supratentorial astrocytomas. J Neurosurg 45: 129-134, 1976

38) Winn HJ: Immune mechanisms in homotransplantation. II. Quantitative assay of the immunologic activity of lymphoid cells stimulated by tumor homografts. J Immun 86: 228-239, 1961

39) Woodruff MFA, Ghaaffar A, Dunbar N, Whitehead VL: Effect of $C$. parvum on immunization with irradiated tumor cells. Br $J$ Cancer 33: 491-495, 1976

40) Yamasaki T, Yamashita J, Handa H, Namba Y, Hanaoka M: Analysis of the peculiarity of immunologic responses to experimental brain tumor. No To Shinkei 35: 229-236, 1983 (in Japanese)

41) Yoshida J, Kobayashi T, Kageyama N: Multimodality treatment of malignant glioma. Effect of chemotherapy with ACNU and immunotherapy with $\mathrm{N}$ CWS. Neurol Med Chir (Tokyo) 24: 19-26, 1984

42) Young H, Kaplan A, Regelson W: Immunotherapy with autologous white cells infusion (lymphocytes) in the treatment of recurrent glioblastoma multiforme. A preliminary report. Cancer 40: 1037-1044, 1977

Address reprint requests to: Y. Kida, M.D., Department of Neurosurgery, School of Medicine, Nagoya University, 65 Tsuruma-cho, Showa-ku, Nagoya 466, Japan. 